Curr Opin Rheumatol. 2014 January ; 26(1): 24-30. doi:10.1097/BOR.0000000000000009.

\title{
Biomarkers in Vasculitis
}

\author{
Paul A. Monach \\ Director, Vasculitis Center, Assistant Professor, Section of Rheumatology, Boston University \\ School of Medicine, 72 East Concord St., E-533, Boston, MA 02118, (617) 414-2503, \\ pmonach@bu.edu
}

\section{Abstract}

Purpose of review-Better biomarkers are needed for guiding management of patients with vasculitis. Large cohorts and technological advances had led to an increase in pre-clinical studies of potential biomarkers.

Recent findings-The most interesting markers described recently include a gene expression signature in CD8+ $\mathrm{T}$ cells that predicts tendency to relapse or remain relapse-free in ANCAassociated vasculitis, and a pair of urinary proteins that are elevated in Kawasaki disease but not other febrile illnesses. Both of these studies used "omics" technologies to generate and then test hypotheses. More conventional hypothesis-based studies have indicated that the following circulating proteins have potential to improve upon clinically available tests: pentraxin-3 in giant cell arteritis and Takayasu's arteritis; von Willebrand factor antigen in childhood central nervous system vasculitis; eotaxin-3 and other markers related to eosinophils or Th2 immune responses in eosinophilic granulomatosis with polyangiitis (Churg-Strauss syndrome); and MMP-3, TIMP-1, and CXCL13 in ANCA-associated vasculitis.

Summary-New markers testable in blood and urine have the potential to assist with diagnosis, staging, assessment of current disease activity, and prognosis. However, the standards for clinical usefulness, in particular the demonstration of either very high sensitivity or very high specificity, have yet to be met for clinically relevant outcomes.

\section{Keywords}

vasculitis; arteritis; biomarkers

\section{Introduction}

Even though the vasculitides are rare diseases, making the diagnosis is usually the easiest part of caring for the patient. Within each form of vasculitis, there is great diversity in the severity of disease and the extent of organ-system involvement, both at diagnosis and later. In most vasculitides, some patients will have monophasic illnesses whereas others will have relapses, either frequently or infrequently. Permanent damage from previous episodes of vasculitis can produce symptoms that are difficult to distinguish from symptoms of active

Conflicts of interest

No conflicts of interest 
vasculitis. Finally, patients on immune-suppressive drugs are at risk for both conventional and opportunistic infections, symptoms of which can also be diificult to distinguish from vasculitis.

Biopsies have imperfect sensitivity due to sampling error and often have inconclusive findings, and repeated biopsies of multiple tissues are not feasible, so less invasive techniques are needed for diagnosis, staging (determining what organs are affected), and assessment of current disease activity. Non-invasive tests to provide short- and long-term prognostic information would also be useful. Unfortunately, the laboratory, imaging, and other tests in common use have limited ability to help the clinician solve these problems. Better tests are needed, with the goals of making care better, safer, and/or less expensive.

The US National Cancer Institute Dictionary defines a biomarker as “... a biological molecule found in blood, other body fluids, or tissues that is a sign of a normal or abnormal process, or of a condition or disease." Although biomarkers can be sought in biopsy specimens in order to provide prognostic information, I will confine my review of vasculitisrelated biomarkers to molecules that can be measured in body fluids, since these represent the bulk of recent research and are the most likely to be developed into clinical tests. However, it is worth noting that such new tests are likely to involve measurement of multiple molecules interpreted via complex equations into summary scores for estimating their predictive value, rather than the quantity of a single protein or metabolite as the clinician is accustomed to seeing.

Biomarker performance is assessed using sensitivity and specificity. These two values are often used to do three additional calculations. Receiver operating characteristic (ROC) curves are made by plotting sensitivity on the $\mathrm{Y}$-axis and (1 - specificity) on the $\mathrm{X}$ - axis, and the area under that curve (AUC) is a summary of overall marker performance, with a value of 1 representing perfect performance and a value of 0.5 indicating no difference from random chance. The positive likelihood ratio $[\mathrm{LR}+=$ sensitivity / $(1-$ specificity)] and the negative likelihood ratio [LR- $=(1-$ sensitivity $) /$ specificity] can be used to determine how a test result would change the odds of one condition versus another. A positive LR of $>8$ or a negative LR of $<0.125$ is often regarded as indicating that a test is good enough at distinguishing two disease states to be considered to be useful in decision-making.

In considering application to clinical problems, LR's are more useful than AUC, because often it is either very high specificity of very high sensitivity that is needed. For example, the positive LR's of anti-PR3 antibodies for granulomatosis with polyangiitis (Wegener's; GPA), of anti-dsDNA antibodies for lupus, and of anti-CCP antibodies for rheumatoid arthritis are all much greater than 8 due to high specificity, and the negative LR for antinuclear antibodies (ANA) for lupus is much lower than 0.125 due to high sensitivity. Conversely, the negative LR's of anti-PR3, anti-dsDNA, and anti-CCP are all much higher than 0.125 , and the positive LR of ANA is much less than 8 . These findings match the clinical use of these tests to rule in or rule out a given disease. However, the approximate AUC's for anti-PR3 (0.9), anti-dsDNA (0.63 - 0.8, difficult to estimate), anti-CCP (0.85), and ANA (0.95) do not capture the relative strengths and limitations of their clinical use. 
Description of these metrics provides an appropriate transition to the important caveats to keep in mind when reading biomarker studies. First, statistical significance will be achieved far more easily than will clinical usefulness. For example, a study with 20-50 patients per group will likely achieve statistical significance with a positive LR of 2 (or a negative LR of 0.5). Secondly, the comparison of disease states being made may not address a clinically important issue, and conversely, the studies that could address the relevant issues may be difficult to perform, for the reasons that are outlined in Table 1 . The majority of biomarker studies involve comparison of patients to healthy controls, or patients with highly active vasculitis to patients in remission. These are not the unmet needs in management of patients with vasculitis, but such studies do provide important starting points for studies with more relevant comparisons, just as observational studies of therapies lead to definitive randomized trials.

\section{Accepted Biomarkers in Vasculitis}

The biomarkers currently in use in vasculitis have been in use longer-usually far longerthan has the term "biomarker." Most of these markers are most useful for diagnosis. Antibodies to proteinase-3 (PR3) or myeloperoxidase (MPO) are highly specific for GPA, microscopic polyangiitis (MPA), and eosinophilic granulomatosis with polyangiitis (ChurgStrauss; EGPA). An elevated peripheral eosinophil count has high sensitivity for EGPA, and a positive cryoglobulin test has high sensitivity for cryogobulinemic vasculitis. Inflammatory markers such as the erythrocyte sedimentation rate (ESR) and $\mathrm{C}$ reactive protein (CRP) have high, but by no means perfect, sensitivity for active vaculitis in untreated patients at first presentation, and thus are useful in ruling out vasculitis, particularly giant cell arteritis (GCA).

All of these markers are problematic for use in assessing disease activity in patients with established diagnoses. Many flares of GPA or MPA are accompanied by increases in antiPR3 or anti-MPO titers; many flares of EGPA by eosinophilia; many flares of cryoglobulinemic vasculitis by hypocomplementemia; and many flares of GCA and other vasculitides by elevated ESR and/or CRP. However, these markers do not appear to have the same predictive value that they do before treatment [1-3•], making their use controversial. Interpreting the literature is difficult for two opposing reasons: the treating physician may use the abnormal marker result to decide whether a flare is occurring (biasing in favor of an association), and the treating physician may be incorrect in determining whether a patient is in remission or not (likely biasing against an association).

The one laboratory test that is highly useful for staging organ involvement is urinalysis, which is thought to have very high sensitivity for active glomerulonephritis (GN), i.e., a normal urinalysis is regarded as ruling out GN. Similarly, the presence of red blood cell casts is regarded as having high specificity (although low sensitivity) for GN. The presence of significant proteinuria is an important marker for staging and prognosis in HenochSchoenlein purpura and is often used to make decisions regarding treatment. However, once kidney damage has occurred due to GN, proteinuria, hematuria, and even red blood cell casts may persist without evidence of progressive kidney disease [4,5], so the high sensitivity and specificity of different aspects of urinalysis are apparent only during the first 
episode of GN. Discovery of urinary markers of active kidney damage would appear to be plausible [5-7], but such markers have not reached clinical use in vasculitis.

\section{Giant Cell Arteritis}

Because temporal artery biopsies are considered to have imperfect sensitivity (60-90\%) for diagnosing GCA, supplementary tests are needed. Much of this need may be met by imaging (ultrasound or MRI of the cranial vessels; ultrasound, MRI/MRA, or PET of the aorta and its branches), but laboratory tests would also be helpful. Although GCA is not thought to be mediated by antibodies, it is still possible that specific autoantibodies might be generated during the inflammatory process. One recent study identified antibodies to a peptide derived from ferritin in patients with GCA and/or polymyalgia rheumatica [8•]. Using healthy controls to establish a reference range, $90 \%$ of untreated patients had such antibodies. However, ability to distinguish a later flare from remission was much lower: I calculated a positive LR of 5.3 and a negative LR of 0.36. Similarly, the rates of positive tests in other inflammatory diseases ranged from $0-33 \%$, or $16 \%$ of all 262 disease controls, giving a positive LR of 5.6-highly statistically significant, and interesting scientifically, but unlikely to be useful clinically.

Few new markers of active arterial inflammation or ongoing arterial damage have been proposed recently, although there have been many papers in the past 20 years showing statistically significant differences in circulating concentrations of various cytokines, proteases, and other proteins. Pentraxin 3 (PTX3), which structurally is in the same family as CRP and serum amyloid A but is made by endothelial cells and activated leukocytes, is the most promising of the recently reported markers, since it had high specificity compared to healthy controls or to patients with rheumatoid arthritis or stable coronary artery disease, and showed some distinction between highly active disease and remission and between patients with and without optic ischemia [9•]. In addition, PTX3 showed poor correlation with ESR or CRP, suggesting that an equation based on multiple markers might improve current laboratory assessment of GCA. Finally, extensive research on temporal artery biopsies, either examined directly [10,11], or cultured [12], or transplanted into immunodeficient mice $[13,14]$, offer many targets to measure in the circulation.

Prognostically, no recent progress has been made beyond the finding, first reported 10 years ago, that patients with greater inflammatory responses at diagnosis (as exemplified by IL-6 levels) have lower rates of ischemic injury but a greater tendency to relapse and to require more prolonged treatment with glucocorticoids $[15,16]$.

\section{Takayasu's Arteritis}

Clinical and laboratory assessment of disease activity in Takayasu's arteritis (TA) are notoriously difficult [17], and no circulating markers for staging or prognosis have been identified. Two recent studies have either found [18] or failed to find [19] support for MMP-3 and MMP-9 as markers of active TA compared to inactive TA or to healthy controls, as reported in an earlier study [20]. One of these recent studies suggested that low levels of the soluble receptor for advanced glycation end products (sRAGE) was a more promising marker for active TA, with an AUC of 0.88 [19]. 
However, the most promising potential biomarker for active TA, as in GCA, is PTX3. A relatively large and well-described study from Italy compared active TA to inactive TA, healthy controls, and acute (localized) bacterial infections [21]. PTX3 distinguished active from inactive TA better than did CRP or ESR (AUC $=0.92,0.68,0.75$ respectively). PTX3 was not elevated at all in acute infections, but multiple previous reports have shown that elevated PTX3 is associated with sepsis and with organ damage or death in sepsis [22,23]. Elevation of PTX3 in active TA was also reported recently in a Japanese cohort, in a study that also found no differences in MMP-3 [24].

\section{Polyarteritis Nodosa and Central Nervous System Vasculitis}

There have been few studies of biomarkers in polyarteritis nodosa (PAN) and, as far as I know, none in primary angiitis of the central nervous system (PACNS) in adults, and these are two diseases in which non-invasive markers for diagnosis, prognosis, and assessment of current activity would be particularly valuable. Autoantibodies to the LAMP-2 protein were recently found to be associated with cutaneous PAN [25], but concentrations overlapped enough with those of healthy controls that this antibody is unlikely to be useful diagnostically.

On this background, a recent report on von Willebrand factor antigen (vWF) in childhood PACNS is notable [26•]. Circulating vWF appeared to track much better with the clinician's global assessment of disease activity than did ESR or CRP. Although rising levels of vWF with age may make this marker problematic in adults, it is much more likely to show specificity for active inflammatory diseases in children.

\section{Eosinophilic Granulomatosis with Polyangiitis (Churg-Strauss, EGPA)}

Eosinophilia, prominent in the circulation as well as in affected tissues, is the hallmark of EGPA, but there is suspicion among experts in this disease that the number of circulating eosinophils may not be an adequate biomarker for active EGPA once a patient has started treatment, since the eosinophil count usually drops dramatically and rapidly after treatment with glucocorticoids. Recent studies have demonstrated elevated concentrations of proteins related to eosinophilia (particularly eotaxin-3) or to Th2 immune responses more generally (IgG4, CCL17/TARC) in active EGPA compared to healthy controls, inactive EGPA, and/or other diseases featuring vasculitis or hypereosinophilia [27-30]. The caveat to all studies comparing active and inactive EGPA is that it is difficult to determine the direct effect of glucocorticoids-commonly needed to control symptoms of asthma and sinonasal disease in EGPA—independent of disease activity.

The most interesting finding of these studies was the much lower level of eotaxin-3 in hypereosinophilic syndromes than in EGPA $[27,28]$ — potentially useful for diagnosis. Another recent study took a very different approach to distinguishing EGPA from asthma or hypereosinophilic syndromes: measurement of eicosanoids in exhaled breath concentrates (EBC). Concentrations of 12-HETE in EBC were markedly higher in EGPA than in the other diseases, even though 19/23 patients were receiving glucocorticoids, and 15/23 were clinically in remission [31•]. 


\section{Granulomatosis with Polyangiitis (Wegener's) and Microscopic Polyangiitis}

There are probably more studies of biomarkers in GPA than in any other form of vasculitis, and the list of circulating proteins that are elevated comparing severe, active GPA to inactive GPA or to healthy controls is long. ESR, CRP, and anti-PR3 or anti-MPO titers are used clinically to assist with determining disease activity and predicting future flares, but as noted above, their usefulness is limited. Because of the larger volume of research in these diseases, my discussion will be selective.

Thirty-eight markers of inflammation, angiogenesis, tissue damage, and repair in 162-186 patients enrolled in a clinical trial $[3 \bullet, 32,33]$. These studies identified MMP-3, TIMP-1, and CXCL13 (BCA-1) as particularly promising markers among many that showed statistically significant differences between groups, and the identification of CXCL13 was novel. These studies are notable for the relatively large numbers of patients and markers, for the analysis of multiple clinical variables, and for analysis of correlations between the concentrations of pairs of markers. The poor correlation of these markers between each other, ESR, and CRP indicates that a model based on multiple markers might have high sensitivity and/or specificity, but development of such a model would require a separate cohort in which to test it. In addition, these studies only compared severe, active vasculitis to remission or to healthy controls, so follow-up studies on clinically relevant endpoints are needed. The same comment applies to other recently-reported markers that show promise [34-37], but among these sRAGE is of particular interest because it may reflect the burden of granulomatous inflammation in GPA [35] and may therefore be useful for assessing "mild" or "limited" disease activity.

The most exciting development in biomarkers for GPA and MPA concerns prediction of relapse rates. First, the observation that patients with anti-MPO antibodies have lower relapse rates than patients with anti-PR3 antibodies has now been reported in multiple cohorts [38-40], and it may be appropriate to use this information to some degree in clinical decision-making. Second, in one of the few cohorts described in which ANCA specificity did not predict relapse rate, a gene expression signature seen only in CD8+ T cells showed strong prediction of a tendency to remain relapse-free, with this finding confirmed in an independent cohort and in another disease, systemic lupus [41]. If this finding can be confirmed in additional cohorts and can be adapted into a test that meets the standards of laboratory medicine, then it may change the way we decide on long-term treatment plans for patients, and the way we view the mechanisms or relapse and remission in autoimmune inflammatory diseases.

\section{Cryoglobulinemic Vasculitis}

Concentrations of cryoglobulins and the $\mathrm{C} 4$ component of complement are used as secondary endpoints in treatment trials of cryoglobulinemic vasculitis [42,43], but the ability of these markers to distinguish the clinical states of complete remission, partial remission, and ongoing active vasculitis is modest [44]. Levels of various inflammatory cytokines and chemokines are higher in patients with cryoglobulinemic vasculitis than in controls [45-49], but it is unclear whether these markers will be of value for clinically relevant endpoints. 
In patients with cryoglobulinemic vasculitis associated with hepatitis $C$ virus infection, eradication of the virus is a very favorable prognostic sign for long-term remission, but cases of recurrent vasculitis without evidence of recurrent viral infection have been reported [50].

\section{Kawasaki Disease}

In Kawasaki Disease (KD), there is a need for a highly sensitive diagnostic test, so as to reduce the number of children receiving unnecessary treatment with IVIG. The N-terminal product of the cleavage reaction that generates B-type natriuretic peptide (NT-proBNP) distinguishes KD from other febrile illnesses, but not well enough to make a clinician confident enough to avoid treatment [51,52]. On this background, use of urine proteomics to identify two proteins, meprin A and filamin C, with very good distinction of KD from nonKD febrile illnesses (AUC 0.98, LR not calculated but with specificity of about $80 \%$ at a cut-off value showing $100 \%$ sensitivity for KD) represents an important advance with potential to be useful clinically [53・•].

A sensitive laboratory test to predict ongoing coronary artery damage despite IVIG would also be of use. A host of traditional markers of inflammation and myocardial injury are higher in KD with than without coronary artery involvement, but not enough to guide decision making [54]. Baseline NT-proBNP also might help distinguish patients who develop coronary artery lesions (despite IVIG) from those who do not, but imperfectly [55]. Decline in urinary meprin A and filamin C showed very good but imperfect discrimination between patients who responded to initial IVIG therapy and patients who required repeat treatment, but development of coronary artery lesions despite treatment was not reported $[53 \bullet \cdot$.

\section{Conclusion}

Recent studies have indicated that we can expect laboratory tests to be developed that will improve diagnosis and management of vasculitis. The use of modern "omics" technologies has produced the most promising advances recently, by searching among many analytes to find the one or few that are most useful. However, there is also a good prospect that markers identified individually by hypothesis-based research will be combined into powerful models for diagnosis or prognosis. In either case, more evaluation is required before any of the recent findings can be used clinically, and the ongoing assembly of relatively large cohorts will be essential to achieving success in this enterprise.

\section{Acknowledgments}

NIH grant: U54 AR057319

\section{References}

1. Tomasson G, Lavalley M, Tanriverdi K, Finkielman JD, Davis JC Jr, Hoffman GS, McCune WJ, St Clair EW, Specks U, Spiera R, et al. Relationship Between Markers of Platelet Activation and Inflammation with Disease Activity in Wegener's Granulomatosis. J Rheumatol. 2011; 38:10481054. [PubMed: 21411717] 
2. Kalsch AI, Csernok E, Munch D, Birck R, Yard BA, Gross W, Kalsch T, Schmitt WH. Use of highly sensitive C-reactive protein for followup of Wegener's granulomatosis. J Rheumatol. 2010; 37:2319-2325. [PubMed: 20716656]

•3. Monach PA, Warner RL, Tomasson G, Specks U, Stone JH, Ding L, Fervenza FC, Fessler BJ, Hoffman GS, Ikle D, et al. Serum proteins reflecting inflammation, injury and repair as biomarkers of disease activity in ANCA-associated vasculitis. Ann Rheum Dis. 2012 A study of 28 serum proteins, chosen to represent diverse processes related to vasculitis, in 186 patients enrolled in a clinical trial, notable for identification of markers with value independent of ESR or CRP.

4. Magrey MN, Villa-Forte A, Koening CL, Myles JL, Hoffman GS. Persistent hematuria after induction of remission in Wegener granulomatosis: a therapeutic dilemma. Medicine (Baltimore). 2009; 88:315-321. [PubMed: 19910745]

5. Lieberthal JG, Cuthbertson D, Carette S, Hoffman GS, Khalidi NA, Koening CL, Langford CA, Maksimowicz-McKinnon K, Seo P, Specks U, et al. urinary biomarkers in relapsing antineutrophil cytoplasmic antibody-associated vasculitis. J Rheumatol. 2013; 40:674-683. [PubMed: 23547217]

6. Haubitz M, Good DM, Woywodt A, Haller H, Rupprecht H, Theodorescu D, Dakna M, Coon JJ, Mischak H. Identification and validation of urinary biomarkers for differential diagnosis and evaluation of therapeutic intervention in anti-neutrophil cytoplasmic antibody-associated vasculitis. Mol Cell Proteomics. 2009; 8:2296-2307. [PubMed: 19564150]

7. Tam FW, Sanders JS, George A, Hammad T, Miller C, Dougan T, Cook HT, Kallenberg CG, Gaskin G, Levy JB, et al. Urinary monocyte chemoattractant protein-1 (MCP-1) is a marker of active renal vasculitis. Nephrol Dial Transplant. 2004; 19:2761-2768. [PubMed: 15353578]

•8. Baerlecken NT, Linnemann A, Gross WL, Moosig F, Vazquez-Rodriguez TR, Gonzalez-Gay MA, Martin J, Kotter I, Henes JC, Melchers I, et al. Association of ferritin autoantibodies with giant cell arteritis/polymyalgia rheumatica. Ann Rheum Dis. 2012; 71:943-947. Identification of an autoantibody associated with PMR and GCA, notable for being a large study that included control groups with other inflammatory diseases—but data from those controls suggest limited clinical utility. [PubMed: 22228484]

•9. Baldini M, Maugeri N, Ramirez GA, Giacomassi C, Castiglioni A, Prieto-Gonzalez S, CorberaBellalta M, Comite GD, Papa I, Dell'antonio G, et al. Selective up-regulation of the soluble pattern-recognition receptor pentraxin 3 and of vascular endothelial growth factor in giant cell arteritis: relevance for recent optic nerve ischemia. Arthritis Rheum. 2012; 64:854-865. One of several papers in GCA and Takayasu's indicating a likely value of pentraxin-3 in assessing disease activity, independent of CRP. [PubMed: 21989653]

10. Visvanathan S, Rahman MU, Hoffman GS, Xu S, Garcia-Martinez A, Segarra M, Lozano E, Espigol-Frigole G, Hernandez-Rodriguez J, Cid MC. Tissue and serum markers of inflammation during the follow-up of patients with giant-cell arteritis--a prospective longitudinal study. Rheumatology (Oxford). 2011; 50:2061-2070. [PubMed: 21873264]

11. Lozano E, Segarra M, Garcia-Martinez A, Espigol-Frigole G, Hernandez-Rodriguez J, Cid MC. New therapeutic targets in giant-cell arteritis. Considerations based on the current pathogenic model and the availability of new therapeutic agents. Clin Exp Rheumatol. 2008; 26:S141-150. [PubMed: 18799072]

12. Corbera-Bellalta M, Garcia-Martinez A, Lozano E, Planas-Rigol E, Tavera-Bahillo I, Alba MA, Prieto-Gonzalez S, Butjosa M, Espigol-Frigole G, Hernandez-Rodriguez J, et al. Changes in biomarkers after therapeutic intervention in temporal arteries cultured in Matrigel: a new model for preclinical studies in giant-cell arteritis. Ann Rheum Dis. 2013

13. Brack A, Rittner HL, Younge BR, Kaltschmidt C, Weyand CM, Goronzy JJ. Glucocorticoidmediated repression of cytokine gene transcription in human arteritis-SCID chimeras. J Clin Invest. 1997; 99:2842-2850. [PubMed: 9185506]

14. Piggott K, Deng J, Warrington K, Younge B, Kubo JT, Desai M, Goronzy JJ, Weyand CM. Blocking the NOTCH pathway inhibits vascular inflammation in large-vessel vasculitis. Circulation. 2011; 123:309-318. [PubMed: 21220737]

15. Hernandez-Rodriguez J, Segarra M, Vilardell C, Sanchez M, Garcia-Martinez A, Esteban MJ, Grau JM, Urbano-Marquez A, Colomer D, Kleinman HK, et al. Elevated production of interleukin-6 is associated with a lower incidence of disease-related ischemic events in patients 
with giant-cell arteritis: angiogenic activity of interleukin- 6 as a potential protective mechanism. Circulation. 2003; 107:2428-2434. [PubMed: 12742994]

16. Hernandez-Rodriguez J, Segarra M, Vilardell C, Sanchez M, Garcia-Martinez A, Esteban MJ, Queralt C, Grau JM, Urbano-Marquez A, Palacin A, et al. Tissue production of pro-inflammatory cytokines (IL-1beta, TNFalpha and IL-6) correlates with the intensity of the systemic inflammatory response and with corticosteroid requirements in giant-cell arteritis. Rheumatology (Oxford). 2004; 43:294-301. [PubMed: 14679293]

17. Kerr GS, Hallahan CW, Giordano J, Leavitt RY, Fauci AS, Rottem M, Hoffman GS. Takayasu arteritis. Ann Intern Med. 1994; 120:919-929. [PubMed: 7909656]

18. Sun Y, Ma L, Yan F, Liu H, Ding Y, Hou J, Jiang L. MMP-9 and IL-6 are potential biomarkers for disease activity in Takayasu's arteritis. Int J Cardiol. 2012; 156:236-238. [PubMed: 22330005]

19. Mahajan N, Dhawan V, Malik S, Jain S. Serum levels of soluble receptor for advanced glycation end products (sRAGE) in Takayasu's arteritis. Int J Cardiol. 2010; 145:589-591. [PubMed: 20579752]

20. Matsuyama A, Sakai N, Ishigami M, Hiraoka H, Kashine S, Hirata A, Nakamura T, Yamashita S, Matsuzawa Y. Matrix metalloproteinases as novel disease markers in Takayasu arteritis. Circulation. 2003; 108:1469-1473. [PubMed: 12952836]

21. Dagna L, Salvo F, Tiraboschi M, Bozzolo EP, Franchini S, Doglioni C, Manfredi AA, Baldissera E, Sabbadini MG. Pentraxin-3 as a marker of disease activity in Takayasu arteritis. Ann Intern Med. 2011; 155:425-433. [PubMed: 21969341]

22. Muller B, Peri G, Doni A, Torri V, Landmann R, Bottazzi B, Mantovani A. Circulating levels of the long pentraxin PTX3 correlate with severity of infection in critically ill patients. Crit Care Med. 2001; 29:1404-1407. [PubMed: 11445697]

23. Uusitalo-Seppala R, Huttunen R, Aittoniemi J, Koskinen P, Leino A, Vahlberg T, Rintala EM. Pentraxin 3 (PTX3) is associated with severe sepsis and fatal disease in emergency room patients with suspected infection: a prospective cohort study. PLoS One. 2013; 8:e53661. [PubMed: 23341967]

24. Ishihara T, Haraguchi G, Kamiishi T, Tezuka D, Inagaki H, Isobe M. Sensitive assessment of activity of Takayasu's arteritis by pentraxin3, a new biomarker. J Am Coll Cardiol. 2011; 57:1712-1713. [PubMed: 21492771]

25. Takeuchi S, Kimura S, Soma Y, Waki M, Yamaguchi M, Nakazawa D, Tomaru U, Ishizu A, Kawakami T. Lysosomal-associated membrane protein-2 plays an important role in the pathogenesis of primary cutaneous vasculitis. Rheumatology (Oxford). 2013

•26. Cellucci T, Tyrrell PN, Pullenayegum E, Benseler SM. von Willebrand factor antigen--a possible biomarker of disease activity in childhood central nervous system vasculitis? Rheumatology (Oxford). 2012; 51:1838-1845. The first study of a potential biomarker of a disease with great need for a sensitive, non-invasive test for disease activity. [PubMed: 22740622]

27. Polzer K, Karonitsch T, Neumann T, Eger G, Haberler C, Soleiman A, Hellmich B, Csernok E, Distler J, Manger B, et al. Eotaxin-3 is involved in Churg-Strauss syndrome--a serum marker closely correlating with disease activity. Rheumatology (Oxford). 2008; 47:804-808. [PubMed: 18397958]

28. Zwerina J, Bach C, Martorana D, Jatzwauk M, Hegasy G, Moosig F, Bremer J, Wieczorek S, Moschen A, Tilg H, et al. Eotaxin-3 in Churg-Strauss syndrome: a clinical and immunogenetic study. Rheumatology (Oxford). 2011; 50:1823-1827. [PubMed: 21266446]

29. Vaglio A, Strehl JD, Manger B, Maritati F, Alberici F, Beyer C, Rech J, Sinico RA, Bonatti F, Battistelli L, et al. IgG4 immune response in Churg-Strauss syndrome. Ann Rheum Dis. 2012; 71:390-393. [PubMed: 22121132]

30. Dallos T, Heiland GR, Strehl J, Karonitsch T, Gross WL, Moosig F, Holl-Ulrich C, Distler JH, Manger B, Schett G, et al. CCL17/thymus and activation-related chemokine in Churg-Strauss syndrome. Arthritis Rheum. 2010; 62:3496-3503. [PubMed: 20669282]

-31. Szczeklik W, Sanak M, Mastalerz L, Sokolowska BM, Gielicz A, Soja J, Kumik J, Musial J, Szczeklik A. 12-hydroxy-eicosatetraenoic acid (12-HETE): a biomarker of Churg-Strauss syndrome. Clin Exp Allergy. 2012; 42:513-522. An innovative approach identifying a biomarker of EGPA (Churg-Strauss) in exhaled breath, distinct from asthma. [PubMed: 22417211] 
32. Monach PA, Kumpers P, Lukasz A, Tomasson G, Specks U, Stone JH, Cuthbertson D, Krischer J, Carette S, Ding L, et al. Circulating angiopoietin-2 as a biomarker in ANCA-associated vasculitis. PLoS One. 2012; 7:e30197. [PubMed: 22279570]

33. Monach PA, Tomasson G, Specks U, Stone JH, Cuthbertson D, Krischer J, Ding L, Fervenza FC, Fessler BJ, Hoffman GS, et al. Circulating markers of vascular injury and angiogenesis in antineutrophil cytoplasmic antibody-associated vasculitis. Arthritis Rheum. 2011; 63:3988-3997. [PubMed: 21953143]

34. Wibisono D, Csernok E, Lamprecht P, Holle JU, Gross WL, Moosig F. Serum HMGB1 levels are increased in active Wegener's granulomatosis and differentiate between active forms of ANCAassociated vasculitis. Ann Rheum Dis. 2010; 69:1888-1889. [PubMed: 20542962]

35. Henes FO, Chen Y, Bley TA, Fabel M, Both M, Herrmann K, Csernok E, Gross WL, Moosig F. Correlation of serum level of high mobility group box 1 with the burden of granulomatous inflammation in granulomatosis with polyangiitis (Wegener's). Ann Rheum Dis. 2011; 70:19261929. [PubMed: 21765168]

36. Takakuwa Y, Kurokawa MS, Ooka S, Sato T, Nagai K, Arito M, Suematsu N, Okamoto K, Nagafuchi H, Yamada H, et al. AC13, a C-terminal fragment of apolipoprotein A-I, is a candidate biomarker for microscopic polyangiitis. Arthritis Rheum. 2011; 63:3613-3624. [PubMed: 21792834]

37. Pepper RJ, Hamour S, Chavele KM, Todd SK, Rasmussen N, Flint S, Lyons PA, Smith KG, Pusey $\mathrm{CD}$, Cook HT, et al. Leukocyte and serum S100A8/S100A9 expression reflects disease activity in ANCA-associated vasculitis and glomerulonephritis. Kidney Int. 2013; 83:1150-1158. [PubMed: 23423260]

38. Harper L, Morgan MD, Walsh M, Hoglund P, Westman K, Flossmann O, Tesar V, Vanhille P, Groot KD, Luqmani R, et al. Pulse versus daily oral cyclophosphamide for induction of remission in ANCA-associated vasculitis: long-term follow-up. Ann Rheum Dis. 2011; 71:955-960. [PubMed: 22128076]

39. Pagnoux C, Hogan SL, Chin H, Jennette JC, Falk RJ, Guillevin L, Nachman PH. Predictors of treatment resistance and relapse in antineutrophil cytoplasmic antibody-associated small-vessel vasculitis: comparison of two independent cohorts. Arthritis Rheum. 2008; 58:2908-2918. [PubMed: 18759282]

40. Pierrot-Deseilligny Despujol C, Pouchot J, Pagnoux C, Coste J, Guillevin L. Predictors at diagnosis of a first Wegener's granulomatosis relapse after obtaining complete remission. Rheumatology (Oxford). 2010; 49:2181-2190. [PubMed: 20675708]

41. McKinney EF, Lyons PA, Carr EJ, Hollis JL, Jayne DR, Willcocks LC, Koukoulaki M, Brazma A, Jovanovic V, Kemeny DM, et al. A CD8+ T cell transcription signature predicts prognosis in autoimmune disease. Nat Med. 2010; 16:586-591. 581p following 591. [PubMed: 20400961]

42. Saadoun D, Resche Rigon M, Thibault V, Longuet M, Pol S, Blanc F, Pialoux G, Karras A, BazinKarra D, Cazorla C, et al. Peg-IFNalpha/ribavirin/protease inhibitor combination in hepatitis C virus associated mixed cryoglobulinemia vasculitis: results at week 24. Ann Rheum Dis. 2013

43. Terrier B, Launay D, Kaplanski G, Hot A, Larroche C, Cathebras P, Combe B, de Jaureguiberry JP, Meyer O, Schaeverbeke T, et al. Safety and efficacy of rituximab in nonviral cryoglobulinemia vasculitis: data from the French Autoimmunity and Rituximab registry. Arthritis Care Res (Hoboken). 2010; 62:1787-1795. [PubMed: 20740617]

44. Ferri C, Cacoub P, Mazzaro C, Roccatello D, Scaini P, Sebastiani M, Tavoni A, Zignego AL, De Vita $S$. Treatment with rituximab in patients with mixed cryoglobulinemia syndrome: results of multicenter cohort study and review of the literature. Autoimmun Rev. 2011; 11:48-55. [PubMed: 21821153]

45. Antonelli A, Fallahi P, Ferrari SM, Corrado A, Sebastiani M, Manfredi A, Frascerra S, Miccoli M, Zignego AL, Ferrannini E, et al. Chemokine (CXC motif) ligand 9 serum levels in mixed cryoglobulinaemia are associated with circulating levels of IFN-gamma and TNF-alpha. Clin Exp Rheumatol. 2012; 30:864-870. [PubMed: 22766105]

46. Antonelli A, Fallahi P, Ferrari SM, Sebastiani M, Manfredi A, Mazzi V, Fabiani S, Centanni M, Marchi S, Ferri C. Circulating CXCL11 and CXCL10 are increased in hepatitis C-associated cryoglobulinemia in the presence of autoimmune thyroiditis. Mod Rheumatol. 2012; 22:659-667. [PubMed: 22160826] 
47. Antonelli A, Ferri C, Ferrari SM, Ghiri E, Marchi S, Colaci M, Bruschi F, Fallahi P. High interleukin-6 and tumor necrosis factor-alpha serum levels in hepatitis $\mathrm{C}$ infection associated or not with mixed cryoglobulinemia. Clin Rheumatol. 2009; 28:1179-1185. [PubMed: 19543846]

48. Antonelli A, Ferri C, Ferrari SM, Ghiri E, Marchi S, Sebastiani M, Fallahi P. Serum concentrations of interleukin 1beta, CXCL10, and interferon-gamma in mixed cryoglobulinemia associated with hepatitis C infection. J Rheumatol. 2010; 37:91-97. [PubMed: 19918044]

49. Sansonno D, Tucci FA, Troiani L, Lauletta G, Montrone M, Conteduca V, Sansonno L, Dammacco F. Increased serum levels of the chemokine CXCL13 and up-regulation of its gene expression are distinctive features of $\mathrm{HCV}$-related cryoglobulinemia and correlate with active cutaneous vasculitis. Blood. 2008; 112:1620-1627. [PubMed: 18550853]

50. Landau DA, Saadoun D, Halfon P, Martinot-Peignoux M, Marcellin P, Fois E, Cacoub P. Relapse of hepatitis $\mathrm{C}$ virus-associated mixed cryoglobulinemia vasculitis in patients with sustained viral response. Arthritis Rheum. 2008; 58:604-611. [PubMed: 18240235]

51. Dahdah N, Siles A, Fournier A, Cousineau J, Delvin E, Saint-Cyr C, Spiegelblatt L, Bonny Y, Vartian M, Montigny M. Natriuretic peptide as an adjunctive diagnostic test in the acute phase of Kawasaki disease. Pediatr Cardiol. 2009; 30:810-817. [PubMed: 19365652]

52. McNeal-Davidson A, Fournier A, Spigelblatt L, Saint-Cyr C, Mir TS, Nir A, Dallaire F, Cousineau J, Delvin E, Dahdah N. Value of amino-terminal pro B-natriuretic peptide in diagnosing Kawasaki disease. Pediatr Int. 2012; 54:627-633. [PubMed: 22414326]

••53. Kentsis A, Shulman A, Ahmed S, Brennan E, Monuteaux MC, Lee YH, Lipsett S, Paulo JA, Dedeoglu F, Fuhlbrigge R, et al. Urine proteomics for discovery of improved diagnostic markers of Kawasaki disease. EMBO Mol Med. 2013; 5:210-220. Use of urine proteomics to identify two proteins with relatively high specificity for KD compared to other febrile illnesses, with validity of the approach confirmed in an independent cohort. [PubMed: 23281308]

54. Chen J, Liu Y, Liu W, Wu Z. A meta-analysis of the biomarkers associated with coronary artery lesions secondary to Kawasaki disease in Chinese children. J Huazhong Univ Sci Technolog Med Sci. 2011; 31:705-711. [PubMed: 22038366]

55. Kaneko K, Yoshimura K, Ohashi A, Kimata T, Shimo T, Tsuji S. Prediction of the risk of coronary arterial lesions in Kawasaki disease by brain natriuretic peptide. Pediatr Cardiol. 2011; 32:11061109. [PubMed: 21487793] 


\section{Key points}

There is a need for better biomarkers in vasculitis: for diagnosis, staging, assessment of current disease activity, and prognosis.

Many studies have found markers that meet statistical significance comparing severe vasculitis to remission or to healthy controls, but few studies have addressed clinically relevant endpoints or have demonstrated high enough sensitivity or specificity to be considered for clinical use.

Progress has been made in identifying circulating proteins that may improve upon tests currently in use, but these markers need to be tested using clinically relevant outcomes.

The most exciting recent advances have used genomic or proteomic technologies to identify expression signatures or proteins of interest, and then tested those markers in independent groups of patients. 


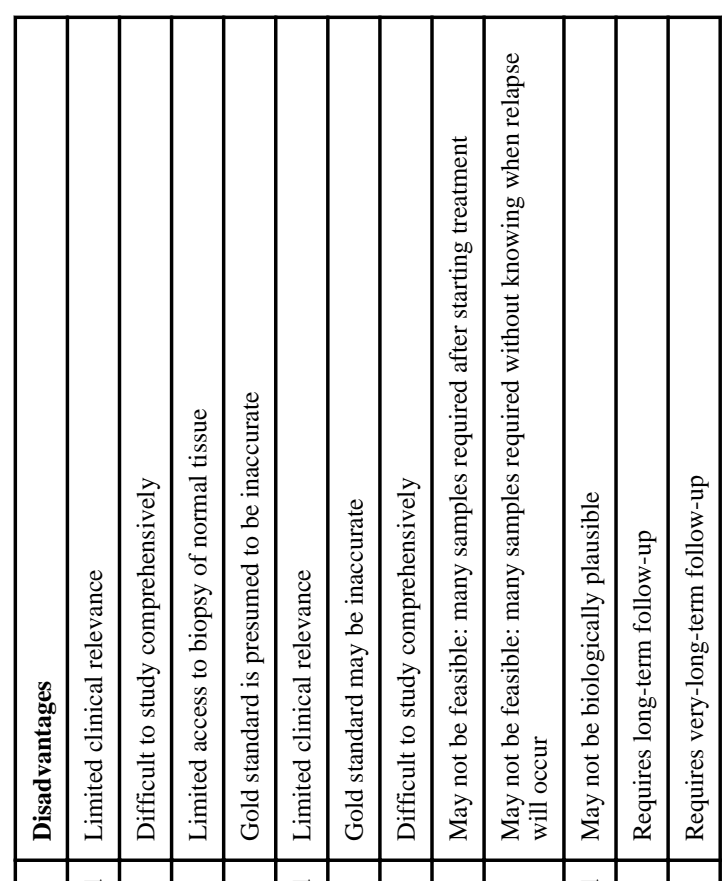



\begin{tabular}{|c|c|c|c|c|c|c|c|c|c|c|c|}
\hline  &  &  &  & \begin{tabular}{|c|} 
\\
\\
0 \\
$\frac{0}{0}$ \\
$\frac{0}{5}$ \\
$\frac{0}{2}$
\end{tabular} &  &  &  &  &  &  & 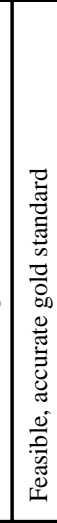 \\
\hline 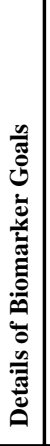 &  &  &  &  &  &  &  &  & 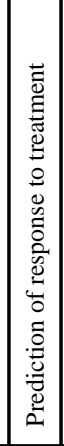 & 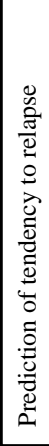 & 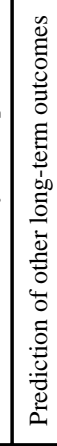 \\
\hline 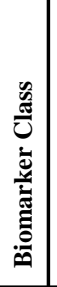 & 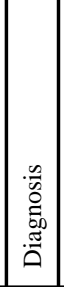 & & 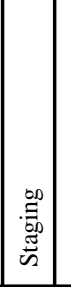 & & 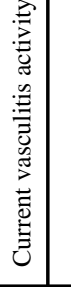 & & 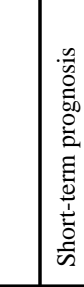 & & 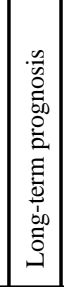 & & \\
\hline
\end{tabular}

Curr Opin Rheumatol. Author manuscript; available in PMC 2015 January 01. 